\title{
Tocopherols and tocotrienols in serum and liver of dairy cows receiving conjugated linoleic acids or a control fat supplement during early lactation
}

\author{
H. Sadri, ${ }^{\dagger}$ S. Dänicke,‡ Ulrich Meyer,ł J. Rehage,§ J. Frank,\# and H. Sauerwein ${ }^{* 1}$ \\ *Institute of Animal Science, Physiology and Hygiene Unit, University of Bonn, 53115 Bonn, Germany \\ †Department of Clinical Science, Faculty of Veterinary Medicine, University of Tabriz, 5166616471 Tabriz, Iran \\ łInstitute of Animal Nutrition, Friedrich-Loeffler-Institute (FLI), 38116 Braunschweig, Germany \\ $\S U n i v e r s i t y$ for Veterinary Medicine, Foundation, 30173 Hannover, Germany \\ \#University of Hohenheim, Institute of Biological Chemistry and Nutrition, 70599 Stuttgart, Germany
}

\section{ABSTRACT}

The fat-soluble vitamin E comprises the 8 structurally related compounds (congeners) $\alpha_{-}, \beta-, \gamma_{-}$, and $\delta$-tocopherol (with a saturated side chain) and $\alpha-, \beta-$, $\gamma$, and $\delta$-tocotrienol (with a 3 -fold unsaturated side chain). Little is known regarding the blood and liver concentrations of the 8 vitamin $\mathrm{E}$ congeners during the transition from pregnancy to lactation in dairy cows. We thus quantified tocopherols $(\mathrm{T})$ and tocotrienols (T3) in serum and liver and hepatic expression of genes involved in vitamin $\mathrm{E}$ metabolism in pluriparous German Holstein cows during late gestation and early lactation and investigated whether dietary supplementation (from d 1 in milk) with conjugated linoleic acids (CLA; $100 \mathrm{~g} / \mathrm{d}$; each $12 \%$ of trans-10,cis-12 and cis9,trans-11 CLA; $\mathrm{n}=11$ ) altered these compared with control-fat supplemented cows (CTR; $\mathrm{n}=10)$. Blood samples and liver biopsies were collected on $\mathrm{d}-21$, 1, 21, 70, and 105 (liver only) relative to calving. In both groups, the serum concentrations of $\alpha \mathrm{T}, \gamma \mathrm{T}, \beta \mathrm{T} 3$, and $\delta \mathrm{T} 3$ increased from $\mathrm{d}-21$ to $\mathrm{d} 21$ and remained unchanged between d 21 and 70, but were unaffected by CLA. The concentrations of the different congeners of vitamin $\mathrm{E}$ in liver did not differ between the CTR and the CLA groups. In both groups, the concentrations of the vitamin $\mathrm{E}$ forms in liver changed during the course of the study. The hepatic mRNA abundance of genes controlling vitamin E status did not differ between groups, but $\alpha$-tocopherol transfer protein and tocopherol-associated protein mRNA increased with time of lactation in both. In conclusion, the concentrations of vitamin E congeners and the expression of genes related to vitamin E status follow characteristic time-related changes during the transition from late gestation to early lactation but are unaffected by CLA supplementation at the dosage used.

Received April 15, 2015

Accepted June 8, 2015.

${ }^{1}$ Corresponding author: sauerwein@uni-bonn.de
Key words: tocopherol, tocotrienol, conjugated linoleic acid, dairy cow

\section{INTRODUCTION}

The term "vitamin E" comprises 8 different natural compounds: $\alpha-, \beta-, \gamma-$, and $\delta$-tocopherol $(\mathbf{T})$ and $\alpha-$, $\beta$-, $\gamma$-, and $\delta$-tocotrienol (T3), of which $\alpha \mathrm{T}$ is the most abundant form in mammals (Frank et al., 2012). Tocopherols have a saturated phytyl side chain and T3 a 3-fold unsaturated isoprenoid side chain. In plasma and tissues of humans and animals, T, and particularly $\alpha \mathrm{T}$, are the predominant congeners and $\mathrm{T} 3$ are usually found at very low concentrations, if at all (Frank et al., 2012). The selective retention of $\alpha \mathrm{T}$ over all other congeners and the particularly low concentrations of T3 are a consequence of the preferential metabolism (initiated by cytochrome P450 monooxygenases) of the non- $\alpha \mathrm{T}$ forms to side-chain shortened water-soluble carboxyethyl hydroxychromanol (CEHC) metabolites in combination with the activity of the hepatic $\alpha$-tocopherol transfer protein (TTP; Grebenstein et al., 2014).

$\alpha$-Tocopherol is the only congener presently used as vitamin E supplement for dairy cows. Plasma vitamin E concentrations decrease gradually throughout the antepartum period, with nadir concentrations around calving and a gradual increase thereafter (Weiss, 1998). The depletion of serum vitamin E concentrations during early lactation may be related to increased incidences of postpartum diseases, such as left displaced abomasum (Qu et al., 2013). Supplementation of dairy cows with vitamin E during the dry period can partially attenuate the decline in plasma vitamin $\mathrm{E}$ concentrations around calving (Politis, 2012). Furthermore, beneficial effects of vitamin E supplementation during the dry period have also been reported; for example, enhancing immune function (Politis et al., 1995, 1996) and decreasing the incidence of clinical mastitis in dairy cows (Smith et al., 1984; Weiss et al., 1997). Such effects seem to depend on the plasma $\alpha \mathrm{T}$ concentration 
achieved and on the infection pressure present in the herds studied (Politis, 2012).

Supplementation with trans-10,cis-12 CLA is used to reduce milk fat content in dairy cows as a dietary strategy aimed to improve energy balance, especially during early lactation (Sippel et al., 2009; Schlegel et al., 2012). The observation that CLA-fed laboratory animals have improved vitamin E status attracted interest in the interaction between vitamin $\mathrm{E}$ and CLA (Liao et al., 2008; Chao et al., 2010). Liver vitamin E concentrations were 15-fold higher in CLA-fed mice than in control animals (Liao et al., 2008). The improved vitamin E status of CLA-treated animals might be due to the induction of TTP expression in the liver (Chen et al., 2012). An increase in longissimus muscle $\alpha \mathrm{T}$ concentration as a result of feeding rumen-protected CLA was also recently reported in young Simmental heifers (Schlegel et al., 2012).

To the best of our knowledge, the effect of dietary CLA on blood and liver concentrations of all vitamin $\mathrm{E}$ congeners and on the hepatic expression of genes involved in the regulation of vitamin $\mathrm{E}$ concentrations has not yet been investigated in dairy cows. The current study was designed to characterize potential effects of CLA supplementation on vitamin E status during the transition from pregnancy to lactation in dairy cows.

\section{MATERIALS AND METHODS}

\section{Animals, Treatment, and Experimental Design}

The experiment was conducted at the experimental station of the Friedrich-Loeffler-Institute (Braunschweig, Germany). The experimental procedures performed in this study were in accordance with European Community regulations concerning the protection of experimental animals and the guidelines of the LAVES (Lower Saxony State office for Consumer Protection and Food Safety, Germany, File Number 33.14.4250204-071/07). Cows, experimental design, and treatments were described in detail by Pappritz et al. (2011). A subset of animals and samples from that study; that is, only pluriparous cows, was considered for the present study. Briefly, 21 German Holstein cows in late gestation were housed in freestall barns and fed ad libitum with a partial mixed ration (6.8 $\mathrm{MJ}$ of $\mathrm{NE}_{\mathrm{L}} /$ $\mathrm{kg}$ of DM) consisting of $37.8 \%$ corn silage, $25.2 \%$ grass silage, and 37\% concentrate (DM basis) during the study period. The concentrate portion of the ration contained $2 \%$ mineral feed (per $\mathrm{kg}$ of mineral feed: 140 $\mathrm{g}$ of $\mathrm{Ca}, 120 \mathrm{~g}$ of $\mathrm{Na}, 70 \mathrm{~g}$ of P, $40 \mathrm{~g}$ of $\mathrm{Mg}, 6 \mathrm{~g}$ of $\mathrm{Zn}$, $5.4 \mathrm{~g}$ of $\mathrm{Mn}, 1 \mathrm{~g}$ of $\mathrm{Cu}, 100 \mathrm{mg}$ of $\mathrm{I}, 40 \mathrm{mg}$ of Se, 5 $\mathrm{mg}$ of Co, 1,000,000 IU of vitamin A, 100,000 IU of vitamin $\mathrm{D}_{3}$, and $1,500 \mathrm{mg}$ of vitamin $\mathrm{E}$ ). Diets were formulated according to the recommendation of the German Society of Nutrition Physiology (GfE, 2001). At 1 DIM, cows were assigned to either the CLA group $(\mathrm{n}=11)$ or control group $(\mathbf{C T R} ; \mathrm{n}=10)$ and fed $100 \mathrm{~g}$ of the respective fat supplements daily until 182 DIM. The fat supplements were incorporated into 4 $\mathrm{kg}$ of additional concentrate (8.8 $\mathrm{MJ}$ of $\mathrm{NE}_{\mathrm{L}} / \mathrm{kg} \mathrm{DM}$ ) consisting of the same components as the concentrate used in the partial mixed ration. Cows in the CLA group received $100 \mathrm{~g} / \mathrm{d}$ of rumen-protected CLA fat (Lutrell Pure, BASF SE, Ludwigshafen, Germany) supplying $7.6 \mathrm{~g}$ of cis-9,trans-11 CLA and $7.6 \mathrm{~g}$ of trans10,cis-12 CLA per day. The CLA supplement contained (\% of total FAME): $\mathrm{C}_{16: 0}(10.9 \%), \mathrm{C}_{18: 0}(50.3 \%), \mathrm{C}_{18: 1}$ cis-9 (10.7\%); $\mathrm{C}_{18: 2}$ cis-9,trans-11 (12.0\%), $\mathrm{C}_{18: 2}$ trans10,cis-12 (11.9\%), other CLA (0.95\%), and other FA (3.3\%). The cows in the CTR group received $100 \mathrm{~g} / \mathrm{d}$ of rumen-protected control fat (Silafat, BASF SE) in which CLA was substituted by stearic acid. The control fat supplement contained ( $\%$ of total FAME): $\mathrm{C}_{16: 0}$ (10.9\%), $\mathrm{C}_{18: 0}(87.3 \%), \mathrm{C}_{18: 1}$ cis-9 $(<0.01 \%) ; \mathrm{C}_{18: 2}$ cis9,trans-11 (0.06\%), $\mathrm{C}_{18: 2}$ trans-10,cis-12 (0.02\%), other CLA $(0.15 \%)$, and other FA (1.58\%).

\section{Blood and Liver Tissue Sampling}

Blood samples were collected via the jugular vein using evacuated tubes. Samples collected on d -21, 1, 21, and 70 relative to parturition were used. All tubes were centrifuged at $4^{\circ} \mathrm{C}$ and $3,000 \times g$ for $10 \mathrm{~min}$ and the serum obtained was kept frozen $\left(-80^{\circ} \mathrm{C}\right)$ until analyzed. Liver tissue samples were obtained on d $-21,1,21,70$, and 105 relative to calving by transcutaneous biopsy using an automatic device (BARD, Tempe, AZ) under ultrasound control. Tissue samples were snap-frozen in liquid nitrogen and stored at $-80^{\circ} \mathrm{C}$.

\section{Quantification of Vitamin E Congeners in Serum Samples}

Tocopherols and T3 were quantified by a validated method described elsewhere (Grebenstein and Frank, 2012). Briefly, serum was thawed on ice and $100 \mu \mathrm{L}$ was transferred to a glass tube. Two milliliters of ethanol containing $1 \%$ ascorbic acid (wt/vol), $900 \mu \mathrm{L}$ of deionized water, and $25 \mu \mathrm{L}$ of butylated hydroxytoluene (BHT; $1 \mathrm{mg} / \mathrm{mL}$ dissolved in ethanol) were added. n-Hexane $(2 \mathrm{~mL})$ was added, hand-mixed by inversion for $1 \mathrm{~min}$, and centrifuged $(5 \mathrm{~min}$, ambient temperature, $800 \times g$ ). A $1.5-\mathrm{mL}$ volume of the supernatant was transferred to a fresh test tube and the extraction repeated. The pooled supernatants were evaporated under vacuum using a centrifugal evaporator (Christ SpeedDry; Christ, Osterode Germany) and the dried residues resuspended 
in $100 \mu \mathrm{L}$ of methanol:water (85:15; vol/vol); then, 10 $\mu \mathrm{L}$ of the suspension was injected into a Jasco HPLC system (AS-950 Plus autosampler, PU-980 Plus pump, FP-950 Plus fluorescence detector, LG-980-02 gradient unit, and a 3-line degasser; Jasco, Groß-Umstadt, Germany). Congeners were separated on a Kinetex PFP column $(2.6 \mu \mathrm{m}, 150 \times 4.6 \mathrm{~mm}$; Phenomenex, Aschaffenburg, Germany) with a methanol:water (85:15, $\mathrm{vol} / \mathrm{vol}$ ) mobile phase delivered at a flow rate of $0.8 \mathrm{~mL} /$ min. The fluorescence detector was operated at an excitation wavelength of $296 \mathrm{~nm}$ and emission wavelength of $325 \mathrm{~nm}$. Peaks were recorded and integrated using ChromPass version 1.8.6.1 (Jasco). The concentrations of $\mathrm{T}$ and $\mathrm{T} 3$ were quantified against external standard curves with authentic compounds (Sigma Aldrich, St. Louis, MO).

\section{Quantification of Vitamin E Congeners in Liver Samples}

Liver vitamin $\mathrm{E}$ concentrations were determined as described for serum with the exception of an additional saponification step added before extraction (Grebenstein and Frank, 2012). For this purpose, $2 \mathrm{~mL}$ of ethanol containing $1 \%$ ascorbic acid (wt/vol), 900 $\mu \mathrm{L}$ of deionized water, and $300 \mu \mathrm{L}$ of saturated $\mathrm{KOH}$ were added to $200 \mathrm{mg}$ of liver tissue. Samples were saponified for $30 \mathrm{~min}$ at $70^{\circ} \mathrm{C}$ in a shaking water bath and then cooled on ice. Butylated hydroxytoluene (25 $\mu \mathrm{L}$ of a $1 \mathrm{mg} / \mathrm{mL}$ ethanolic solution), $1 \mathrm{~mL}$ of deionized water, and $300 \mu \mathrm{L}$ of glacial acetic acid were added and the samples subsequently treated as described above for serum.

In the CLA group, the analyses had to be limited to samples from liver collected on DIM 21 and 105 because the liver samples collected on DIM 1 and 70 in this group had been used for other analyses and the amount of tissue remaining was insufficient for a reliable analysis.

\section{RNA Extraction and Quantitative Real-Time Reverse Transcription-PCR}

Total RNA was extracted from the liver homogenates using Trizol (Invitrogen, Karlsruhe, Germany) and purified using spin columns (RNeasy Mini Kit, Qiagen, Hilden, Germany) according to the manufacturer's instructions and with DNase treatment. The concentration and purity of RNA was assessed by measuring the absorbance at 260 and $280 \mathrm{~nm}$ using a Nanodrop 1000 (peQLab Biotechnology, Erlangen, Germany). The integrity of the RNA was assessed using ethidium bromide-denaturing RNA electrophoresis and rechecked in selected samples using an Agilent 2100 Bioanalyzer and RNA 6000 Nano Kit system (Agilent, Waldbronn, Germany) according to the manufacturer's protocol. Reverse transcription (RT) was carried out with $250 \mathrm{ng}$ of total RNA per $20-\mu \mathrm{L}$ reaction using $200 \mathrm{U}$ of Revert Aid reverse transcriptase, $500 \mu M$ of each deoxynucleotide triphosphate, and $20 \mathrm{U}$ of RiboLock ribonuclease inhibitor (Fermentas, St. Leon-Rot, Germany), with 200 pmol of random hexamer primers (Sigma-Aldrich, Nümbrecht, Germany) for $10 \mathrm{~min}$ at $27^{\circ} \mathrm{C}, 60 \mathrm{~min}$ at $42^{\circ} \mathrm{C}$, and $1 \mathrm{~min}$ at $99^{\circ} \mathrm{C}$. A negative template control and a no-reverse-transcriptase control were included in each run. Reverse transcription was carried out in duplicate for each sample.

Analysis by quantitative real-time RT-PCR was performed in an Mx3000P cycler (Stratagene, Amsterdam, the Netherlands). The characteristics of the primers and the real-time PCR conditions are shown in Table 1. The reaction was performed in triplicate in a total volume of $10 \mu \mathrm{L}$ composed of $2 \mu \mathrm{L}$ of cDNA (diluted 1:4) as template, $1 \mu \mathrm{L}$ of the assay-specific primer mix, $5 \mu \mathrm{L}$ of the SYBR Green JumpStart Taq Readymix (Sigma-Aldrich, Steinheim, Germany), and $2 \mu \mathrm{L}$ of water. A negative-template control for quantitative PCR, as well as a negative-template control and no-reversetranscriptase control of cDNA were included in each run. Inter-run variation was corrected by including inter-run calibrator. Melting curve analysis confirmed the presence of a single product for each real-time RTPCR assay. For each PCR reaction, a standard curve was generated using serial dilution of cDNA to calculate efficiency-corrected relative quantities of the targets. The real-time PCR efficiency rates of the investigated transcripts ranged from 1.94 to 2.05 .

Three reference genes; namely, eukaryotic translation initiation factor 3, subunit K (EIF3K), low-density lipoprotein receptor-related protein 10 (LRP10), and RNA polymerase II (POLR2A) were used to normalize gene expression data (Saremi et al., 2012). The expression stability of the reference genes was validated using geNorm (Vandesompele et al., 2002).

\section{Statistical Analyses}

Statistical analysis of the data was carried out using SAS software (version 9.3; SAS Institute Inc., Cary, $\mathrm{NC}$ ). The data were tested for normality before analysis using the UNIVARIATE procedure. When the data were not normally distributed, they were transformed using a $\log _{10}$ transformation before analysis. The data were analyzed using repeated measures in the MIXED procedure of SAS. The model included treatment, time (sampling date), and interaction of treatment $\times$ time 
Table 1. Characteristics of primers and real-time PCR conditions

\begin{tabular}{|c|c|c|c|c|c|c|}
\hline Gene $^{1}$ & Sequence ( 5 to $\left.3^{\prime}\right)$ & $\begin{array}{l}\text { NCBI } \\
\text { accession no. }\end{array}$ & $\begin{array}{l}\text { Length } \\
\text { (bp) }\end{array}$ & $\begin{array}{c}\text { Concentration } \\
(\mathrm{n} M)\end{array}$ & $\begin{array}{l}\text { Mean } \\
\mathrm{Cq}^{2}\end{array}$ & $\begin{array}{c}\text { Annealing } \\
\text { conditions }{ }^{3} \\
\left(\mathrm{~s} /{ }^{\circ} \mathrm{C}\right)\end{array}$ \\
\hline \multicolumn{7}{|l|}{$T T P$} \\
\hline Reverse & CCTAGAGACCTGATGCAGCG & & & & & \\
\hline \multicolumn{7}{|l|}{ TAP } \\
\hline Forward & GCAGCGATCCTGGCATCTAT & NM_177943.2 & 109 & 200 & 20.3 & $30 / 61$ \\
\hline Forward & ACAAGCCGCTCTTGACAGAA & NM_001035042.1 & 196 & 1,000 & 22.6 & $60 / 58$ \\
\hline Reverse & GAGGCGACGAGAGTTGTTGT & & & & & \\
\hline \multicolumn{7}{|c|}{ 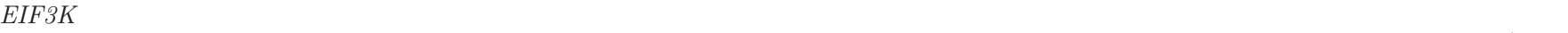 } \\
\hline Forward & CCAGGCCCACCAAGAAGAA & NM_001034489 & 125 & 400 & 22.2 & $45 / 59$ \\
\hline Reverse & TTATACCTTCCAGGAGGTCCATGT & & & & & \\
\hline \multicolumn{7}{|c|}{ ( } \\
\hline Forward & CCAGAGGATGAGGACGATGT & BC149232 & 139 & 400 & 21.1 & $30 / 61$ \\
\hline
\end{tabular}

${ }^{1} T T P=\alpha$-tocopherol transfer protein; $T A P=$ tocopherol-associated protein; $C Y P 4 F 2=$ cytochrome $\mathrm{P}_{450} 4 \mathrm{~F} 2 ;$ EIF3K $=$ eukaryotic translation initiation factor 3 , subunit $\mathrm{K} ; L R P 10=$ lipoprotein receptor-related protein 10; POLR2A = RNA polymerase II.

${ }^{2}$ Mean quantification cycle.

${ }^{3}$ Initial denaturation for $10 \mathrm{~min}$ at $90^{\circ} \mathrm{C}$; denaturation for $30 \mathrm{~s}$ at $95^{\circ} \mathrm{C}$; extension for $30 \mathrm{~s}$ at $72^{\circ} \mathrm{C}$, except for $T T P$ and $C Y P 4 F 2\left(60 \mathrm{~s}\right.$ at $\left.72^{\circ} \mathrm{C}\right)$.

as the fixed effects and cow as the random effect. The compound symmetry was determined as the most appropriate covariance structure for all repeated statements according to the Akaike information criterion. Prepartum data were included in the statistical model as a covariate. The Tukey-Kramer adjustment was used to account for multiple comparisons. Data presented in this paper show the nontransformed values of the data; however, all $P$-values were calculated using the transformed data where necessary. The threshold of significance was set at $P<0.05$; trends were declared at $0.05<P<0.10$.

\section{RESULTS}

\section{Milk Fat Content and DMI}

The dietary supplementation of CLA during early lactation gradually decreased milk fat percentage and resulted in a significant $12 \%$ reduction from wk 8 of supplementation onward, thus confirming the effectiveness of the CLA treatment, as described previously (Pappritz et al., 2011).

During the postpartum period, DMI did not differ between groups (Figure 1) and was $22.3 \pm 0.24 \mathrm{~kg} / \mathrm{d}$ (mean $\pm \mathrm{SEM}$ ) and $21.2 \pm 0.24 \mathrm{~kg} / \mathrm{d}$ in the CTR and CLA groups, respectively. The DMI increased with time $(P<0.01)$, and an interaction of treatment $\times$ time was observed $(P<0.01)$.

\section{Serum and Liver Concentrations of Vitamin E Congeners}

We detected no significant differences between the CTR and CLA groups with respect to the serum concentrations of any of the vitamin E congeners (Figure $2)$. The serum concentrations of $\alpha \mathrm{T}, \gamma \mathrm{T}, \beta \mathrm{T} 3$, and $\delta \mathrm{T} 3$

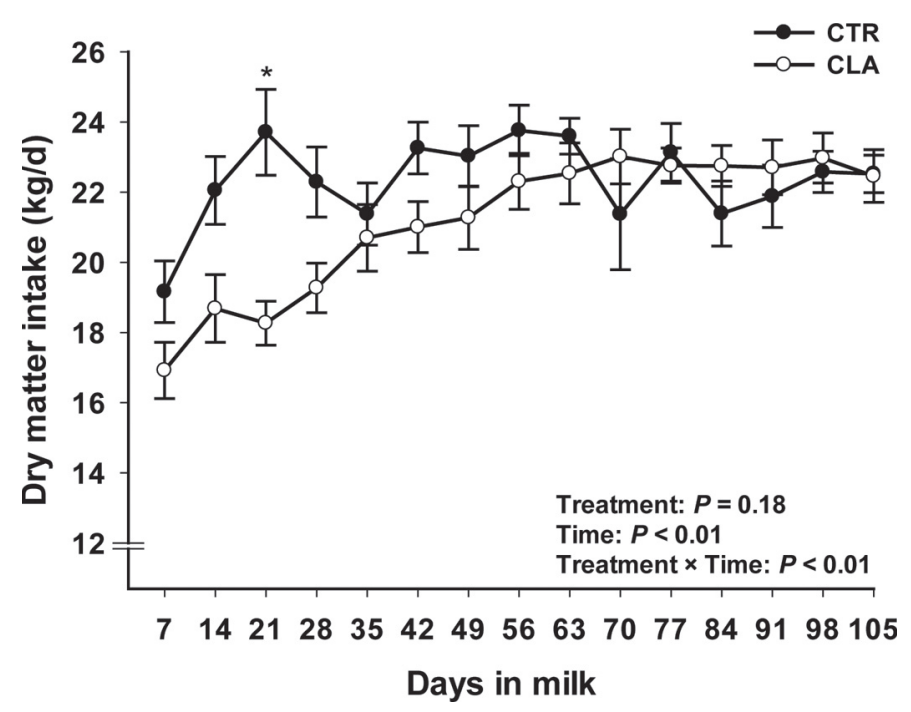

Figure 1. Dry matter intake (means \pm SEM) in dairy cows receiving CLA or a control fat supplement (CTR) from d 1 of lactation. Asterisks indicate a significant difference $(P<0.01)$ between CLA and CTR at a given time point. 
changed over time $(P<0.01)$ and followed a similar pattern in both groups; that is, they increased from $\mathrm{d}$ -21 to $\mathrm{d} 21$ and remained largely unchanged between d 21 and 70. No time-related differences were found for the serum concentrations of $\alpha \mathrm{T} 3$ and $\gamma \mathrm{T} 3$ during the course of the study. For the serum concentrations of $\gamma \mathrm{T} 3$, we observed a trend for a treatment $\times$ time interaction $(P=0.07)$. No treatment $\times$ time interactions were observed for the serum concentrations of any other vitamin $\mathrm{E}$ forms.

No significant differences were observed between the CTR and CLA groups for liver concentrations of any of the vitamin E congeners (Figure 3). Time-related changes in the liver concentrations of the vitamin $\mathrm{E}$ forms were noted in both experimental groups $(P<$ 0.05; $P=0.07$ in case of $\gamma \mathrm{T} 3)$. There was no treatment $\times$ time interaction for any of the vitamin $\mathrm{E}$ forms assessed in liver.

\section{Hepatic Expression of Genes Related to Vitamin E Transport and Metabolism}

The mRNA abundance of TTP was not affected by CLA supplementation but increased 1.62-fold in the CTR group from $d-21$ to $105(P<0.01$; Figure $4 \mathrm{~A})$. A trend was observed for the interaction between treatment $\times$ time for the mRNA abundance of TTP $(P=$ $0.10)$. The abundance of tocopherol-associated protein $(\boldsymbol{T A P})$ mRNA did not differ between the groups, but changed over time and followed a similar pattern in both groups postpartum $(P<0.001$; Figure $4 \mathrm{~B})$. In the postpartum period, TAP mRNA abundance was greater on d 105 than on $\mathrm{d} 70$ (2.80- and 2.70-fold for the CTR and CLA groups, respectively). No treatment $\times$ time interaction was observed for TAP mRNA abundance. The mRNA abundance of cytochrome $\mathrm{P}_{450} 4 \mathrm{~F} 2$ (CYP4F2) was not affected by treatment or time and there was no treatment $\times$ time interaction.

\section{DISCUSSION}

Little is known regarding the changes in total vitamin $\mathrm{E}(\mathrm{T}+\mathrm{T} 3)$ concentrations in dairy cows during the period between pregnancy and early lactation, because previous studies only quantified $\alpha \mathrm{T}$ alone or together with $\gamma \mathrm{T}$, but not T3. However, T3 might also significantly contribute to vitamin E status. The blood concentrations of $\alpha \mathrm{T}$ in dairy cows decrease gradually throughout the antepartum period, reaching a nadir at parturition and increase thereafter (Weiss, 1998; Weiss et al., 2009; Qu et al., 2013). Our observations confirm this time course in the postpartum period only, as the serum concentrations of $\alpha \mathrm{T}$ in the both groups were increased within $3 \mathrm{wk}$ postpartum to relatively con- stant concentrations that were higher than before and at calving (d 1). However, due to the study design, we were unable to assess potential changes during the first days after calving. In the present study, the unchanged serum $\alpha \mathrm{T}$ concentrations between $\mathrm{d}-21$ and $\mathrm{d} 1$ are not in agreement with previous studies (Weiss, 1998; Qu et al., 2013), which reported a decrease in circulating $\alpha \mathrm{T}$ concentrations in the antepartum period in dairy cows. At present, we have no explanation for this unexpected result.

In the present study, the serum concentrations of $\gamma \mathrm{T}$, $\beta \mathrm{T} 3$, and $\delta \mathrm{T} 3$ were far below those of $\alpha \mathrm{T}$ (on average $93 / 6,527,1 / 6,527$, and $2 / 6,527$, respectively), but showed mostly similar patterns across time as $\alpha \mathrm{T}$.

In the present study, feed samples were no longer available for laboratory analyses. Therefore, one limitation of our study is the absence of compositional data and subsequently intake data for $\mathrm{T}$ and $\mathrm{T} 3$. The absence of these data makes it difficult to determine whether the higher concentration of $\alpha \mathrm{T} 3$ compared with other T3 isomers in the serum reflected the dietary source or a potential bio-discrimination in the absorption of the different T3. The passage of digesta through the ruminant gastrointestinal tract is a complex process involving ruminal fermentation processes, selective retention, mixing, degradation, and escape of particles and liquid from the rumen before passing to the small and large intestines. Furthermore, in ruminants, because of the continuous flow of digesta to the small intestine, the secretion of bile, enzymes, and digestive juices is continuous and not subjected to large cyclic changes as observed in nonruminants. This may lead to differences in the metabolism and thus retention (and ultimately tissue concentrations) of vitamin $\mathrm{E}$ in ruminants compared with nonruminants. These results suggest that T3 may follow alternative metabolic pathways that warrant further investigation.

The selective deposition of $\alpha \mathrm{T}$ and its secretion to the circulation results from preferential postabsorptive elimination of congeners of vitamin $\mathrm{E}$ other than $\alpha \mathrm{T}$. Consequently, $\alpha \mathrm{T}$ is retained to the greatest extent, followed by $\gamma \mathrm{T}(2-20 \%$ of total vitamin $\mathrm{E})$, whereas the T3 are eliminated rapidly (Frank et al., 2012). To date, 2 mechanisms are known to contribute to the selective retention of $\alpha \mathrm{T}$ and discrimination against the non$\alpha \mathrm{T}$ congeners. One is a $32-\mathrm{kDa}$ cytosolic protein, TTP, expressed predominantly in liver, with different relative binding affinities for $\mathrm{T}$ and $\mathrm{T} 3$ as follows: natural $\alpha \mathrm{T}$, $100 \%$; $\beta \mathrm{T}, 38 \% ; \gamma \mathrm{T}, 9 \%$; $\delta \mathrm{T}, 2 \%$, and $\alpha \mathrm{T} 3,12 \%$ (Hosomi et al., 1997). There is no information available regarding the relative binding affinities of TTP toward the other T3. The second mechanism is related to CYP4F2, which is expressed predominantly in liver and catalyzes the hydroxylation of the terminal methyl group of the 
A)
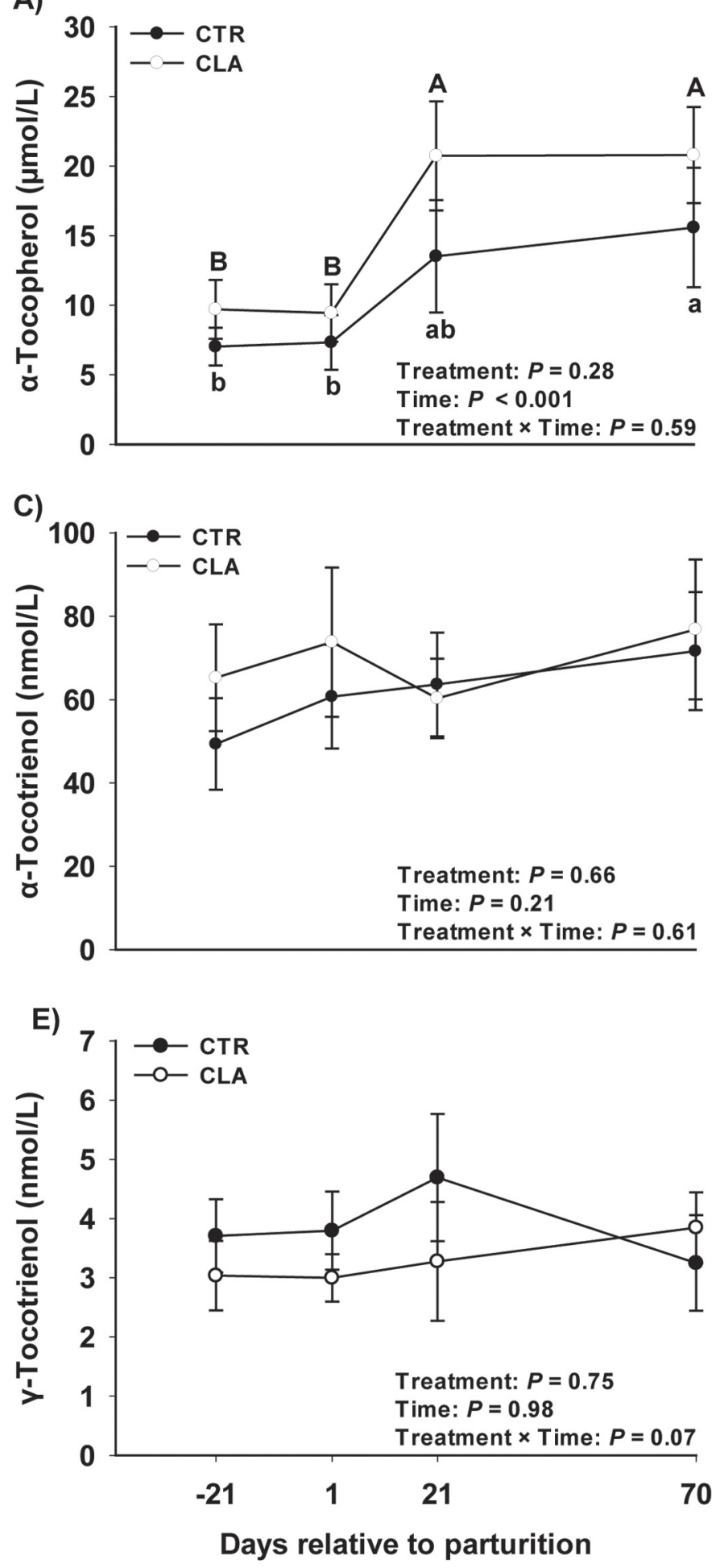

B)

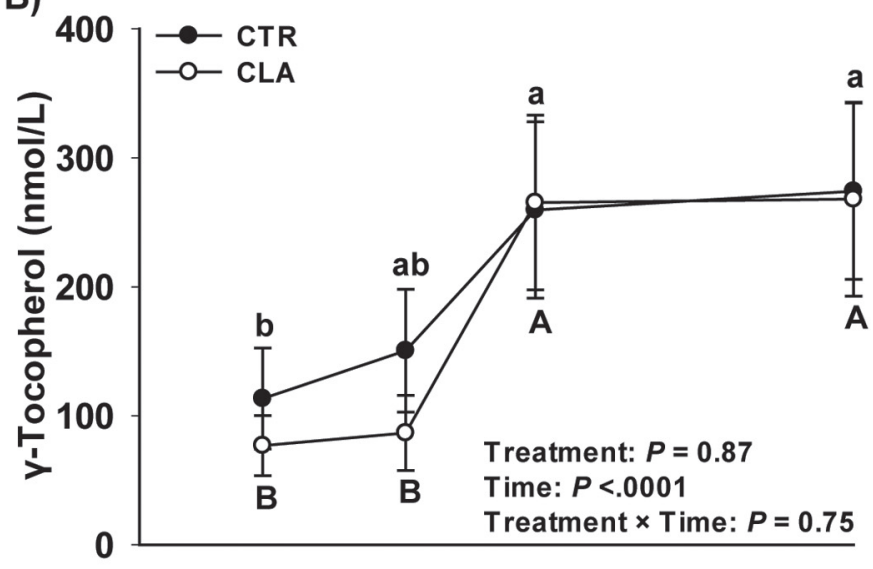

D)
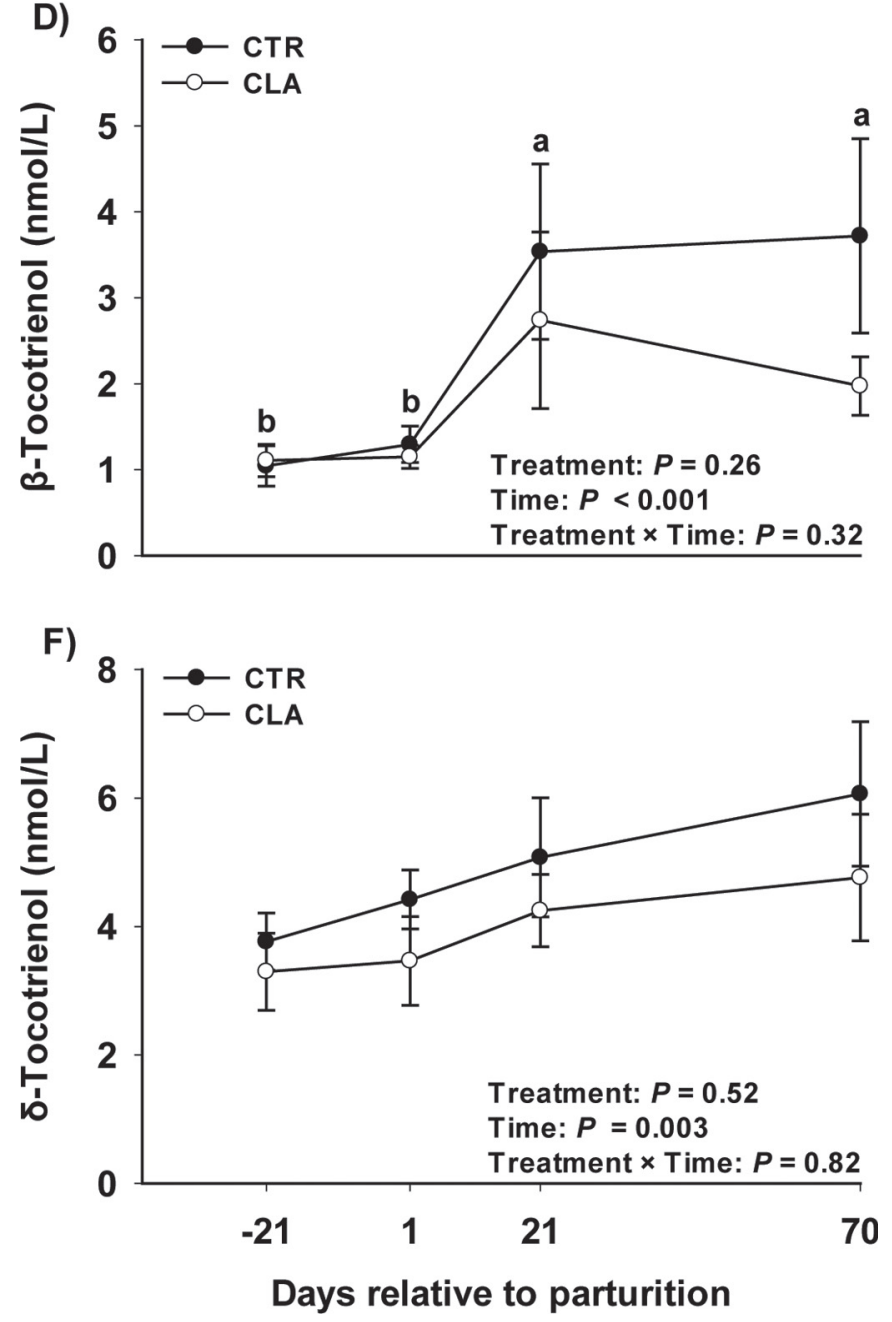

Figure 2. Time course of the serum concentrations (means \pm SEM) of $\alpha$-tocopherol (A), $\gamma$-tocopherol (B), $\alpha$-tocotrienol $(\mathrm{C}), \beta$-tocotrienol (D), $\gamma$-tocotrienol (E), and $\delta$-tocotrienol (F) in dairy cows during late gestation and early lactation. Supplementation with CLA or control fat (CTR) was initiated at $\mathrm{d} 1$ of lactation. Different letters indicate differences $(P<0.05)$ between the time points in the control $(\mathrm{CTR})(\mathrm{a}, \mathrm{b})$, and in the CLA (A, B) group, respectively. When summing all tocopherols $(\alpha \mathrm{T}+\gamma \mathrm{T}=\Sigma \mathrm{T})$, all tocotrienols $(\alpha \mathrm{T} 3+\beta \mathrm{T} 3+\gamma \mathrm{T} 3+\delta \mathrm{T} 3=\Sigma \mathrm{T} 3)$, and all vitamin $\mathrm{E}$ congeners $(\Sigma \mathrm{T}+\Sigma \mathrm{T} 3)$, the $P$-values for treatment were $0.28(\Sigma \mathrm{T}), 0.83(\Sigma \mathrm{T} 3)$, and $0.28(\Sigma \mathrm{T}+\Sigma \mathrm{T} 3)$; for time, the $P$-values were $<0.0001[\Sigma \mathrm{T}$ and $(\Sigma \mathrm{T}+\Sigma \mathrm{T} 3)]$ and $0.06(\Sigma \mathrm{T} 3)$; there was no treatment $\times$ time interaction in any of the summed variables. 

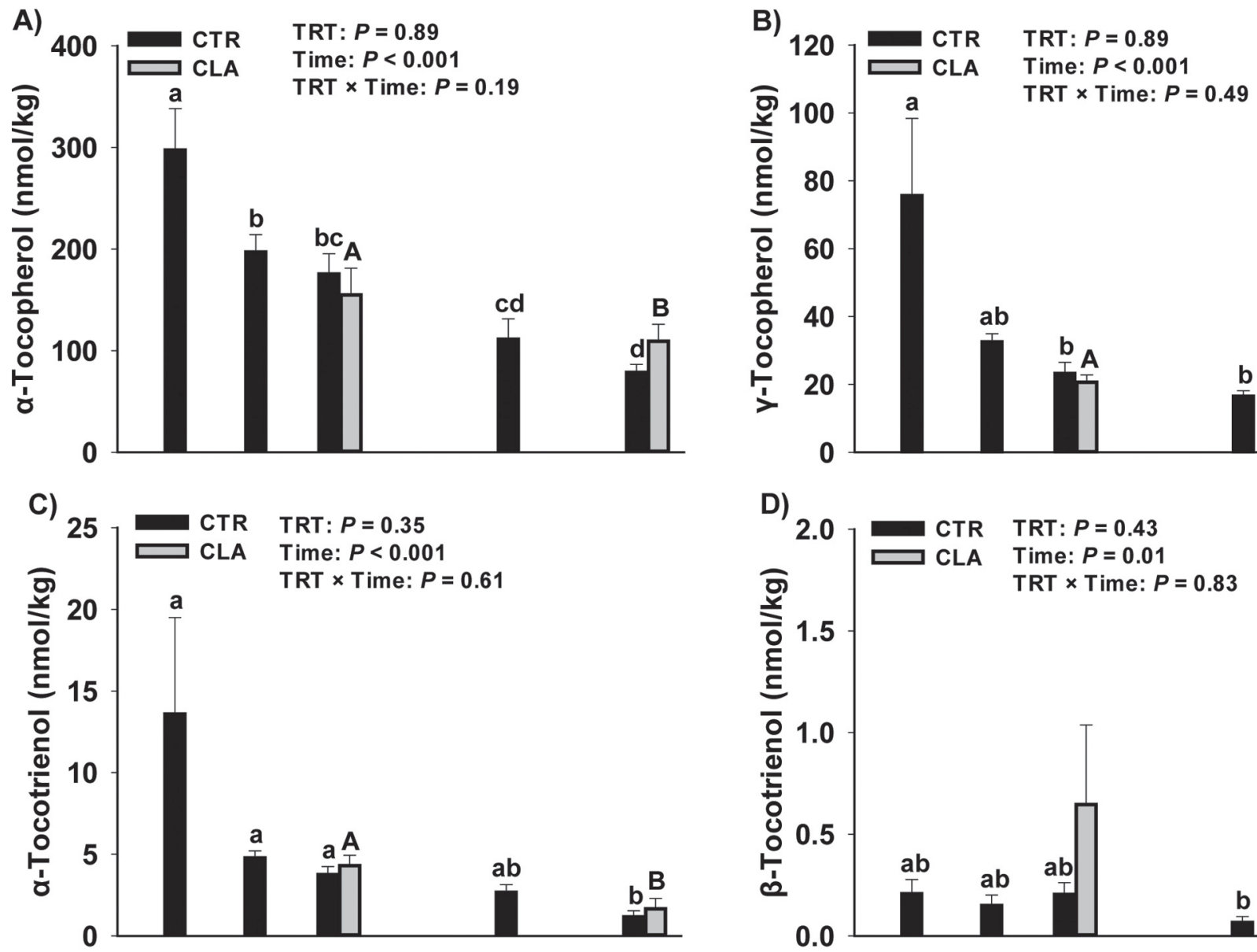

D)
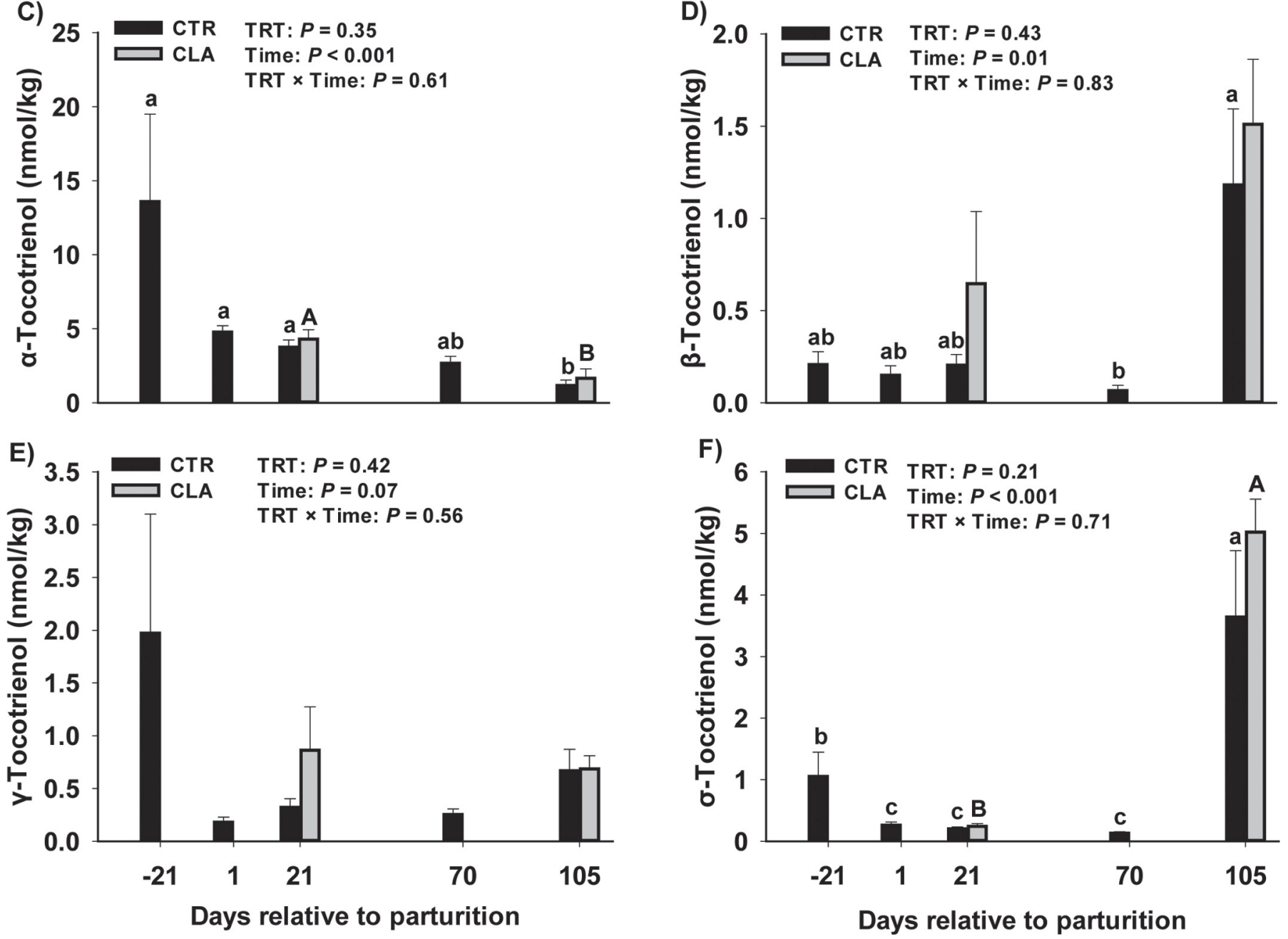

Figure 3. Time course of the hepatic concentrations (means \pm SEM) of $\alpha$-tocopherol (A), $\gamma$-tocopherol (B), $\alpha$-tocotrienol (C), $\beta$-tocotrienol $(\mathrm{D}), \gamma$-tocotrienol $(\mathrm{E})$, and $\delta$-tocotrienol $(\mathrm{F})$ in dairy cows during late gestation and early lactation. Supplementation with CLA or control fat $(\mathrm{CTR})$ was initiated at d 1 of lactation. Different letters indicate differences $(P<0.05)$ between the time points in the control $(\mathrm{CTR}$; a-d) and in the CLA (A, B) group, respectively. 
A)
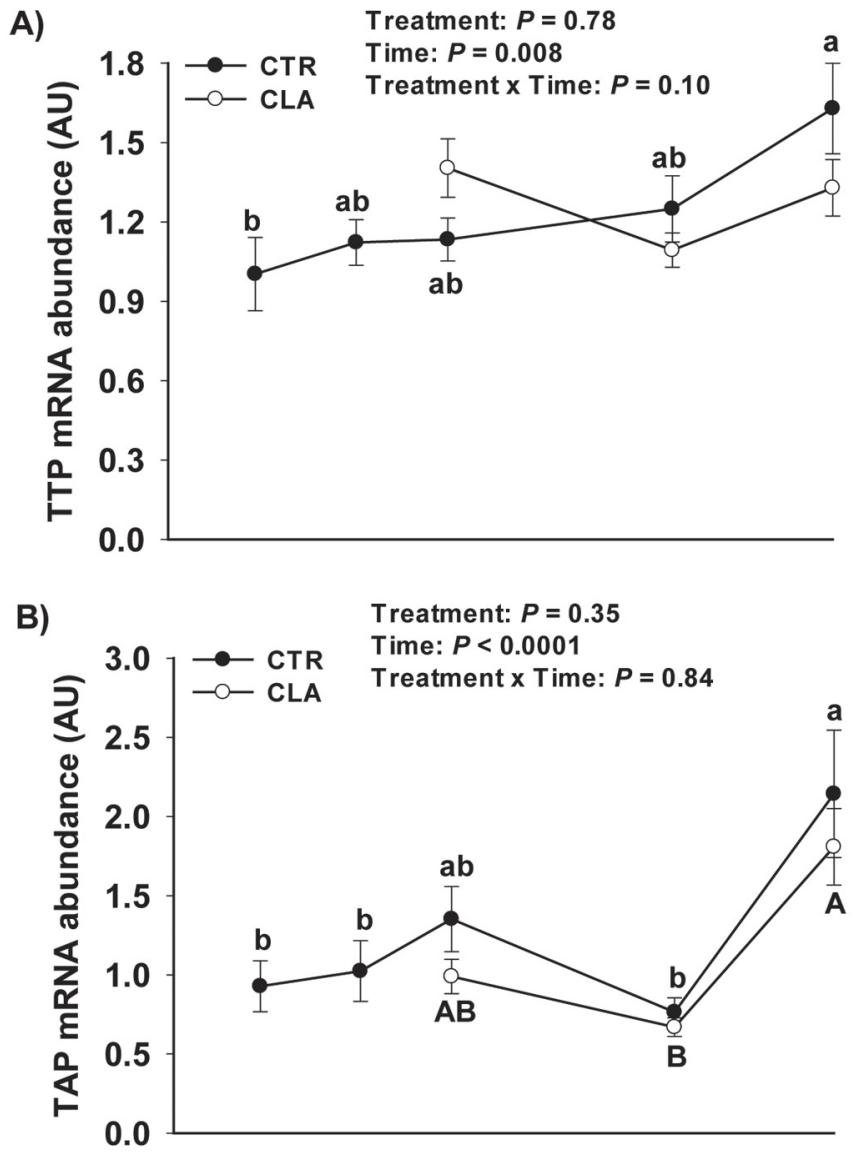

C)

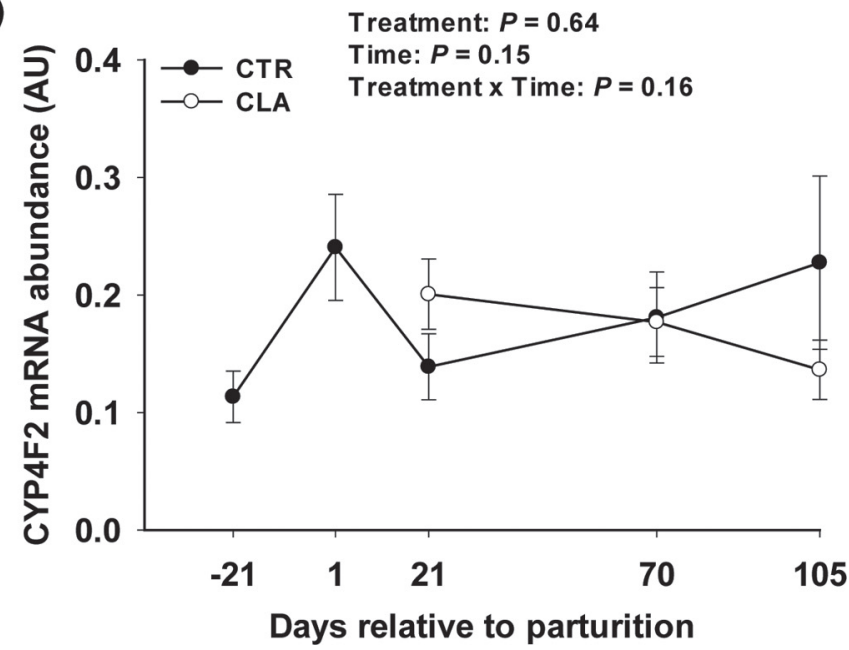

Figure 4. Time course of hepatic mRNA abundance (means \pm SEM) of $\alpha$-tocopherol transfer protein (TTP, A), tocopherol-associated protein (TAP, B), and cytochrome P450 4F2 (CYP4F2, C) in dairy cows during late gestation and early lactation. Supplementation with CLA or control fat (CTR) was initiated at d 1 of lactation. Different letters indicate differences $(P<0.05)$ between the time points in the control $(\mathrm{CTR})(\mathrm{a}, \mathrm{b})$ and in the $\mathrm{CLA}(\mathrm{A}, \mathrm{B})$ group, respectively. side-chain of vitamin E. This enzyme displays a higher activity toward non- $\alpha \mathrm{T}$ congeners (Sontag and Parker, $2002,2007)$. Inhibition of tocopherol-w-hydroxylation by lignans or alkylresorcinols leads to increased plasma concentrations of $\gamma \mathrm{T}$ (Parker et al., 2000; Ross et al., 2004; Grebenstein et al., 2014) and reduced excretion of its short-chain metabolite $\gamma \mathrm{CEHC}$ (Frank et al., 2008), suggesting an important role of this pathway in the regulation of vitamin E status. In support of this, Grebenstein et al. (2014) recently reported that vitamin $\mathrm{E}$ metabolism, not TTP, is responsible for the selective retention of $\alpha \mathrm{T}$ and discrimination against $\gamma \mathrm{T}$. Interestingly, Chen et al. (2012) reported that the liver $\alpha \mathrm{T}$ concentrations were 7 times higher in CLAsupplemented mice than in the control group. They found that neither absorption nor degradation of $\alpha \mathrm{T}$ to $\alpha \mathrm{CEHC}$ was affected by CLA supplementation. Induction of TTP mRNA and protein expression was demonstrated as the crucial factor for the improved vitamin $\mathrm{E}$ status in the CLA-fed mice (Chen et al., 2012). In the present study, in the CTR group, liver $\alpha \mathrm{T}$ concentrations changed inversely over time compared with that of serum $\alpha \mathrm{T}$. On the other hand, the expression of TTP mRNA changed during the course of the study, being higher (1.62-fold) on d 105 compared with $\mathrm{d}-21$. This indicates an involvement of TTP in the increase of $\alpha \mathrm{T}$ concentrations in the serum. It has already been documented that TTP binds $\alpha \mathrm{T}$, facilitates its secretion via lipoproteins, and thus determines its concentration in circulation (Hosomi et al., 1997). Thus, the more $\alpha \mathrm{T}$ is secreted, the less $\alpha \mathrm{T}$ is retained in the liver. Our results indicate an improvement in hepatic release of $\alpha \mathrm{T}$ into the circulation to support target tissues postpartum. The increase in serum $\alpha \mathrm{T}$ concentrations on $\mathrm{d} 21$ and 70 compared with d 1 and d -21 might also be in response to increased feed intake postpartum. Therefore, we cannot determine whether the increase in serum $\alpha \mathrm{T}$ concentrations $3 \mathrm{wk}$ after parturition in the present study was mainly a consequence of increased feed intake, upregulation of TTP expression, or a combination of both, although the latter seems most likely.

The involvement of CYP4F2 in the observed changes in serum and liver vitamin $\mathrm{E}$ is unlikely, as its mRNA abundance did not change over time. Alternatively, it may indicate that posttranscriptional modifications of this factor came into play and may have concealed an involvement, as it has recently been shown that vitamin E metabolism, not TTP, is required for the selective retention of $\alpha \mathrm{T}$ and discrimination against $\gamma \mathrm{T}$ (Grebenstein et al., 2014). Further studies including protein expression and activity of selected factors may provide additional clues to the involvement of factors in vitamin $\mathrm{E}$ metabolism during the periparturient period in dairy cows. 
The increase in vitamin E status of laboratory animals supplemented with CLA has focused attention on the interactions between vitamin E and CLA (Liao et al., 2008; Chao et al., 2010). Thus, in the current study, we hypothesized that dietary supplementation with CLA during early lactation might influence serum and liver concentrations of the various vitamin $\mathrm{E}$ congeners by altering the hepatic mRNA abundance of genes related to vitamin $\mathrm{E}$ status in dairy cows. In addition to $\alpha \mathrm{T}$ and $\gamma \mathrm{T}$, all $4 \mathrm{~T} 3$ were detected in serum and liver of dairy cows during late gestation and early lactation. In spite of lower DMI during the first days of lactation (significantly on d 21 and numerically on d 7, 14, and 28; Figure 1) and thus presumably lower vitamin E intake in the CLA group, serum $\alpha \mathrm{T}$ concentrations did not differ between the CLA-supplemented and CTR cows (Figure 2A). Thus, CLA might help to retain $\alpha \mathrm{T}$ in serum.

Tocopherol-associated protein, also named SEC14-like 2 (SEC14L2), is a cytosolic protein that is expressed in many human tissues, with higher expression in the liver, brain, and prostate (Zimmer et al., 2000). In contrast to TTP, TAP seems to have a broad affinity for small lipid molecules, including various vitamin $\mathrm{E}$ isoforms and some phospholipids (Kempná et al., 2003). In the present study, upregulation of TAP mRNA abundance on d 105 compared with d 70 in the CTR and CLA groups coincided with the greater hepatic concentrations of $\beta \mathrm{T} 3$ and $\delta \mathrm{T} 3$. We thus speculate that TAP might be selectively involved in the accumulation of $\beta \mathrm{T} 3$ and $\delta \mathrm{T} 3$ in the liver, perhaps by limiting access to bound tocotrienols of the degrading enzymes. However, the mechanism and function of the TAP upregulation observed herein remains to be elucidated.

\section{CONCLUSIONS}

All 4 congeners of T3 were detected in serum and liver of dairy cows during the transition from pregnancy to lactation, albeit at distinctively lower concentrations than $\alpha \mathrm{T}$ and $\gamma \mathrm{T}$. The increase in TTP mRNA abundance with DIM in the CTR group may show an involvement of TTP in the increase of $\alpha \mathrm{T}$ concentrations in the serum. The data indicate time-related changes in the serum and liver concentrations of the vitamin $\mathrm{E}$ congeners and in the hepatic expression of genes involved in the regulation of vitamin $\mathrm{E}$ concentrations, but they were not affected by the CLA supplement at the dosage used in the present study.

\section{ACKNOWLEDGMENTS}

The authors express their appreciation to the Deutsche Forschungsgemeinschaft (DFG, Berlin, Ger- many) for the financial support of the project (PAK 286/1, SA 432/10-1); to Inga Hofs and Isabella Israel (Institute of Animal Science, Physiology and Hygiene Unit, University of Bonn, Germany) for their excellent laboratory assistance as well as to Iris Gockel-Böhner (Institute of Animal Science, Physiology and Hygiene Unit, University of Bonn) for her help during sampling of the cows.

\section{REFERENCES}

Chao, P. M., W. H. Chen, C. H. Liao, and H. M. Shaw. 2010. Conjugated linoleic acid causes a marked increase in liver $\alpha$-tocopherol and liver $\alpha$-tocopherol transfer protein in C57BL/6J mice. Int. J. Vitam. Nutr. Res. 80:65-73.

Chen, W. H., Y. J. Li, M. S. Wang, Z. C. Kang, H. L. Huang, and H. M. Shaw. 2012. Elevation of tissue $\alpha$-tocopherol levels by conjugated linoleic acid in C57BL/6J mice is not associated with changes in vitamin $\mathrm{E}$ absorption or $\alpha$-carboxyethyl hydroxychroman production. Nutrition 28:59-66.

Frank, J., X. W. Chin, C. Schrader, G. P. Eckert, and G. Rimbach. 2012. Do tocotrienols have potential as neuroprotective dietary factors? Ageing Res. Rev. 11:163-180.

Frank, J., S. Lee, S. W. Leonard, J. K. Atkinson, A. Kamal-Eldin, and M. G. Traber. 2008. Sex differences in the inhibition of gammatocopherol metabolism by a single dose of dietary sesame oil in healthy subjects. Am. J. Clin. Nutr. 87:1723-1729.

GfE (German Society of Nutrition Physiology). 2001. Ausschuss für Bedarfsnormen der Gesellschaft für Ernährungsphysiologie. Nr. 8. Empfehlungen zur Energie- und Nährstoffversorgung der Milchkühe und Aufzuchtrinder (Recommendations of energy and nutrient supply for dairy cows and breeding cattle). DLG-Verlag, Frankfurt am Main, Germany.

Grebenstein, N., and J. Frank. 2012. Rapid baseline-separation of all eight tocopherols and tocotrienols by reversed-phase liquidchromatography with a solid-core pentafluorophenyl column and their sensitive quantification in plasma and liver. J. Chromatogr. A 1243:39-46.

Grebenstein, N., M. Schumacher, L. Graeve, and J. Frank. 2014. Tocopherol transfer protein is not required for the discrimination against $\gamma$-tocopherol in vivo but protects it from side-chain degradation in vitro. Mol. Nutr. Food Res. 58:1052-1060.

Hosomi, A., M. Arita, Y. Sato, C. Kiyose, T. Ueda, O. Igarashi, H. Arai, and K. Inoue. 1997. Affinity for alpha-tocopherol transfer protein as a determinant of the biological activities of vitamin $\mathrm{E}$ analogs. FEBS Lett. 409:105-108.

Kempná, P., J. M. Zingg, R. Ricciarelli, M. Hierl, S. Saxena, and A. Azzi. 2003. Cloning of novel human SEC14p-like proteins: Ligand binding and functional properties. Free Radic. Biol. Med. 34:1458-1472.

Liao, C. H., H. M. Shaw, and P. M. Chao. 2008. Impairment of glucose metabolism in mice induced by dietary oxidized frying oil is different from that induced by conjugated linoleic acid. Nutrition $24: 744-752$

Pappritz, J., U. Meyer, R. Kramer, E. M. Weber, G. Jahreis, J. Rehage, G. Flachowsky, and S. Dänicke. 2011. Effects of long-term supplementation of dairy cow diets with rumen-protected conjugated linoleic acids (CLA) on performance, metabolic parameters and fatty acid profile in milk fat. Arch. Anim. Nutr. 65:89-107.

Parker, R. S., T. J. Sontag, and J. E. Swanson. 2000. Cytochrome P4503A-dependent metabolism of tocopherols and inhibition by sesamin. Biochem. Biophys. Res. Commun. 277:531-534.

Politis, I. 2012. Reevaluation of vitamin E supplementation of dairy cows: Bioavailability, animal health and milk quality. Animal 6:1427-1434.

Politis, I., M. Hidiroglou, T. R. Batra, J. A. Gilmore, R. C. Gorewit, and H. Scherf. 1995. Effects of vitamin E on immune function of dairy cows. Am. J. Vet. Res. 56:179-184. 
Politis, I., N. Hidiroglou, J. H. White, J. A. Gilmore, S. N. Williams, H. Scherf, and M. Frigg. 1996. Effects of vitamin E on mammary and blood leukocyte function, with emphasis on chemotaxis, in periparturient dairy cows. Am. J. Vet. Res. 57:468-471.

Qu, Y., K. Lytle, M. G. Traber, and G. Bobe. 2013. Depleted serum vitamin $\mathrm{E}$ concentrations precede left displaced abomasum in early-lactation dairy cows. J. Dairy Sci. 96:3012-3022.

Ross, A. B., Y. Chen, J. Frank, J. E. Swanson, R. S. Parker, A. Kozubek, T. Lundh, B. Vessby, P. Aman, and A. Kamal-Eldin. 2004. Cereal alkylresorcinols elevate gamma-tocopherol levels in rats and inhibit gamma-tocopherol metabolism in vitro. J. Nutr. 134:506510 .

Saremi, B., A. Al-Dawood, S. Winand, U. Müller, J. Pappritz, D. von Soosten, J. Rehage, S. Dänicke, S. Häussler, M. Mielenz, and H. Sauerwein. 2012. Bovine haptoglobin as an adipokine: serum concentrations and tissue expression in dairy cows receiving a conjugated linoleic acids supplement throughout lactation. Vet. Immunol. Immunopathol. 146:201-211.

Schlegel, G., R. Ringseis, W. Windisch, F. J. Schwarz, and K. Eder. 2012. Effects of a rumen-protected mixture of conjugated linoleic acids on hepatic expression of genes involved in lipid metabolism in dairy cows. J. Dairy Sci. 95:3905-3918.

Sippel, M. A., R. S. Spratt, and J. P. Cant. 2009. Milk production responses of primiparous and multiparous dairy cows to dose of conjugated linoleic acid consumed in rumen inert form. Can. J. Anim. Sci. 89:393-399.

Smith, K. L., J. H. Harrison, D. D. Hancock, D. A. Todhunter, and H. R. Conrad. 1984. Effect of vitamin E and selenium supplementa- tion on incidence of clinical mastitis and duration of clinical symptoms. J. Dairy Sci. 67:1293-1300.

Sontag, T. J., and R. S. Parker. 2002. Cytochrome P450 omega-hydroxylase pathway of tocopherol catabolism. Novel mechanism of regulation of vitamin E status. J. Biol. Chem. 277:25290-25296.

Sontag, T. J., and R. S. Parker. 2007. Influence of major structural features of tocopherols and tocotrienols on their-oxidation by tocopherol-omega-hydroxylase. J. Lipid Res. 48:1090-1098.

Vandesompele, J., K. De Preter, F. Pattyn, B. Poppe, N. Van Roy, A. De Paepe, and F. Speleman. 2002. Accurate normalization of real-time quantitative RT-PCR data by geometric averaging of multiple internal control genes. Genome Biol. 3:research0034.1-research0034.11.

Weiss, W. P. 1998. Requirements of fat-soluble vitamins for dairy cows: A review. J. Dairy Sci. 81:2493-2501.

Weiss, W. P., J. S. Hogan, D. A. Todhunter, and K. L. Smith. 1997. Effect of vitamin E supplementation in diets with a low concentration of selenium on mammary gland health of dairy cows. J. Dairy Sci. 80:1728-1737.

Weiss, W. P., J. S. Hogan, and D. J. Wyatt. 2009. Relative bioavailability of all-rac and RRR vitamin E based on neutrophil function and total $\alpha$-tocopherol and isomer concentrations in periparturient dairy cows and their calves. J. Dairy Sci. 92:720-731.

Zimmer, S., A. Stocker, M. N. Sarbolouki, S. E. Spycher, J. Sassoon, and A. Azzi. 2000. A novel human tocopherol-associated protein: Cloning, in vitro expression, and characterization. J. Biol. Chem. 275:25672-25680. 